\title{
Pengaruh Kompleksitas Operasi Perusahaan, Ukuran Kap dan Audit Tenure terhadap Audit Delay
}

\section{The Relationship between Complexity of the Company's Size of Public Accounting Firm and Tenure Audit the Audit Delay}

\author{
Intan Puspa Dewi ${ }^{1}$, Auliffi Ermian Challen ${ }^{1}$ \\ Program Studi Akuntansi, Fakultas Ekonomi Universitas YARSI, Jakarta \\ E-mail koresponden: auliffi.ermian@yarsi.ac.id
}

KEYWORDS Audit Delay, Complexity of the Company's, Size of Public Accounting Firm and Tenure Audit.

ABSTRACT This research is conducted in order to analyse the relationship between complexity of the company's, size of public accounting firm and tenure audit to audit delay to the manufacturing companies listed in the Indonesia Stock Exchange in the period 2011-2015. The sample in this research was secondary data and selected by using purposive sampling method. The population of this research consist of 143 companies listed in the Indonesia Stock Exchange (IDX). And samples used in this research as many as 95 companies. The analytical method used is multiple linear regression analysis. The result of this research showed that size of public accounting firm have negative impact to the audit delay, while the complexity of the company's and tenure audit do not have effect to the audit delay.

\section{PENDAHULUAN}

Laporan keuangan merupakan hal yang penting bagi investor untuk menilai kinerja dan tanggung jawab manajemen perusahaan. Laporan keuangan adalah laporan yang menunjukkan kondisi keuangan perusahaan pada saat ini atau dalam suatu periode tertentu. Maksud laporan keuangan yang menunjukkan kondisi perusahaan saat ini adalah kondisi terkini perusahaan. Berhasil tidaknya perusahaan dapat dinilai dengan melihat laporan keuangan yang diterbitkan setiap tahunnya. Apabila laporan keuangan menunjukkan nilai positif, maka hal itu dapat menarik para investor untuk menanamkan modal pada perusahaan tersebut (Ilhami, 2015).

Menurut Ardianti (2013), para pemakai dari laporan keuangan akan menggunakannya untuk meramalkan, membandingkan, dan menilai dampak keuangan yang timbul dari keputusan ekonomis yang diambilnya. Informasi laporan keuangan akan lebih bermanfaat apabila informasi dalam laporan keuangan yang disajikan lebih akurat, relevan, dan tepat waktu. Otoritas Jasa Keuangan mengeluarkan Peraturan Otoritas Jasa Keuangan No.42/POJK.04/2016 tentang Laporan Bursa Efek yang menyatakan bahwa Bursa Efek wajib menyampaikan laporan 
kegiatan kepada Otoritas Jasa Keuangan yang meliputi laporan keuangan tengah tahunan paling lambat 60 (enam puluh) hari sejak tanggal akhir periode dan laporan keuangan tahunan paling lambat 90 (sembilan puluh) hari sejak tanggal akhir tahun buku yang telah diaudit oleh Akuntan yang terdaftar di Otoritas Jasa Keuangan disertai pendapat dari Akuntan tersebut.

Di Bursa Efek Indonesia, masih terdapat perusahaan-perusahaan yang terlambat menyerahkan laporan keuangannya. Manajemen PT Bursa Efek Indonesia (BEI) menghentikan perdagangan (suspensi) saham PT Ratu Prabu Energi Tbk (ARTI) pada 31 Oktober 2016. Selain itu, otoritas bursa juga memperpanjang suspensi perdagangan efek untuk 13 perusahaan tercatat. Suspensi itu dilakukan lantaran hingga 29 Oktober 2016, 14 perusahaan tercatat belum menyampaikan laporan keuangan interim per 30 Juni 2016. Perusahaan tercatat itu juga belum melakukan pembayaran denda atas keterlambatan penyampaian laporan keuangan. Berdasarkan aturan bursa terutama Peraturan Nomor I-H : tentang sanksi, bursa memberikan peringatan tertulis III dan tambahan denda sebesar Rp 150 juta kepada perusahaan tercatat yang terlambat sampaikan laporan keuangan dan pembayaran denda atas keterlambatan itu. Otoritas bursa mensuspensi apabila mulai hari kalender ke-91 sejak lampaunya batas waktu penyampaian laporan keuangan, perusahaan tercatat telah menyampaikan laporan keuangan yang tidak memenuhi kewajiban membayar denda. Hal itu mengacu pada ketentuan II.6.4 peraturan Nomor I-H tentang sanksi. Perusahaan tercatat yang kena suspensi antara lain PT Borneo Lumbung Energi dan Metal Tbk (BORN), PT Berau Coal Energy Tbk
(BRAU), PT Bakrie Telecom Tbk (BTEL), PT Buana Listya Tama Tbk (BULL), PT Global Teleshop Tbk (GLOB), PT Inovisi Infracom Tbk (INVS), dan PT Capitalinc Investment Tbk (MTFN). Selain itu, PT Skybee Tbk (SKYB), PT Permana Prima Sakti Tbk (TKGA), PT Trikomsel Oke Tbk (TRIO), PT Ratu Prabu Energi Tbk (ARTI), PT Garda Tujuh Buana Tbk (GTBO), PT Sekawan Intipratama Tbk (SIAP), dan PT Siwani Makmur Tbk (SIMA) (Liputan6.com, 2016).

Menurut Ito Warsito, Direktur Utama Bursa Efek Indonesia mengatakan, meski tidak mempengaruhi transaksi perdagangan saham di bursa, namun dengan adanya perusahaan yang terlambat mengirimkan laporan keuangan dapat menjadi contoh yang kurang baik bagi emiten lainnya. Kemungkinan ada banyak hal yang membuat emiten terlambat memberikan laporan keuangan, seperti konsolidasi ataupun pergantian akuntan publik yang melakukan audit. Emiten besar juga ada yang pernah terlambat memberikan laporan keuangan, contohnya Telkom, namun alasannya waktu itu karena konsolidasi dengan anak usaha belum selesai (ANTARANews, 2012).

Menurut Prasongkoputra (2013), perbedaan waktu antara tanggal laporan keuangan dengan tanggal opini audit dalam laporan keuangan mengindikasikan tentang lamanya waktu penyelesaian audit yang dilakukan oleh auditor, kondisi ini sering disebut audit delay. Audit delay yang menyebabkan lamanya publikasi laporan keuangan, dapat sangat merugikan investor karena dapat meningkatkan asimetri informasi dan menimbulkan rumor dari para pelaku pasar yang membuat pasar menjadi tidak pasti. 
Pada umumnya perusahaan memiliki tingkat operasi yang kompleks. Kompleksitas operasi suatu emiten tingkatannya bergantung pada keberadaan, jumlah dan lokasi unit perusahaan (cabang) serat diverifikasi jalur produk dan pasarnya. Hal ini cenderung mempengaruhi waktu yang dibutuhkan auditor untuk menyelesaikan pekerjaan auditnya. Sehingga dapat juga mempengaruhi ketepatan waktu penyampaian laporan keuangan perusahaan publik (Kholishah, 2013). Dalam penelitian Ardianti (2013), Fitriyani et al. (2015), dan Setyaningrum (2015), menemukan bahwa kompleksitas perusahaan berpengaruh positif signifikan terhadap audit delay. Namun Mustafa (2011), menemukan bahwa kompleksitas operasi perusahaan tidak berpengaruh terhadap ketepatan waktu penyampaian laporan keuangan.

$$
\text { Menurut Ratnaningsih \& }
$$
Dwirandra (2016) menyatakan bahwa audit tenure dapat meningkatkan pemahaman dan pengalaman dalam mempelajari karakteristik perusahaan. Dalam penelitiannya menemukan bahwa kegagalan audit sering terjadi di tahun pertama terjadinya perikatan antara auditor dan perusahaan saat menjalin hubungan, dibandingkan dengan auditor yang telah mengaudit klien untuk jangka waktu yang lebih panjang. Hal ini sejalan dengan penelitian yang dilakukan oleh Ardianti (2013) yang menyimpulkan bahwa audit tenure berpengaruh signifikan terhadap audit delay. Lain halnya dalam penelitian Praptika \& Rasmini (2016) dan Rustiarini \& Sugiarti (2013), hasil penelitian menunjukkan lamanya waktu penugasan (audit tenure) tidak berpengaruh terhadap audit delay.

Perusahaan dengan jenis manufaktur biasanya memiliki rentan waktu pelaporan laporan keuangan (audit delay) yang lebih panjang. Dalam penelitian Marhayaacob \& Ahmad (2012) mengemukakan bahwa perusahaan konstruksi dan manufaktur lebih memiliki rentan waktu yag panjang dalam pelaporan keuangannya daripada perusahaan berbasis non-manufaktur. Ini dikarenakan dalam menafsirkan segala asetnya, perusahaan maufaktur lebih sulit untuk dinilai daripada perusahaan nonmanufaktur.

Berdasarkan penelitian sebelumnya dan penjelasan di atas masih terjadi research gap yang menunjukkan adanya keanekaragaman dari hasil penelitian tentang faktor-faktor yang mempengaruhi audit delay. Oleh sebab itu, penulis melakukan penelitian kembali terhadap faktor kompleksitas operasi perusahaan, ukuran KAP dan audit tenure untuk membuktikan gap yang muncul. Peneliti juga mengambil sampel pada penelitian ini adalah perusahaan manufaktur yang terdaftar di Bursa Efek Indonesia (BEI). Penelitian ini bertujuan memberikan informasi agar mengetahui pengaruh kompleksitas operasi perusahaan, ukuran KAP dan audit tenure terhadap rentang waktu penyelesaian laporan audit (audit delay) sehingga dapat dijadikan untuk digunakan sebagai bahan pertimbangan saat berinvestasi.

\section{METODOLOGI}

Peneliti menggunakan desain
penelitian asosiatif kausal untuk
menganalisis bagaimana suatu variabel
mempengaruhi variabel lain, dan melihat
dampaknya pada variabel dependen
secara langsung. Dalam penelitian ini
akan menjelaskan bagaimana pengaruh
variabel-variabel terhadap audit delay.
Kemudian dengan berdasarkan analisa


yang akan dilakukan maka akan ditentukan apakah variabel-variabel tersebut berpengaruh. Metode yang digunakan dalam penelitian ini adalah metode kuantitatif. Populasi dalam penelitian ini adalah seluruh perusahaan manufaktur yang terdaftar di Bursa Efek Indonesia sebanyak 143 perusahaan, metode penentuan sampel yang dilakukan adalah metode puposive sampling, dengan sampel yang diperoleh sebanyak 95 perusahaan manufaktur yang terdaftar selama periode 2011, 2012, 2013, 2014 dan 2015. Operasionalisasi variabel yang dipakai dalam penelitian ini dapat dilihat pada Tabel 1.

Tabel 1. Operasionalisasi Variabel

\begin{tabular}{|c|c|c|}
\hline Variabel & Indikator & Skala \\
\hline Audit Delay (Y) & $\begin{array}{l}\text { Jumlah hari yang dihitung dari = (tanggal penutupan tahun buku } \\
\text { perusahaan - tanggal penerbitan laporan auditan) }\end{array}$ & Rasio \\
\hline Kompleksitas & Variabel dummy, & Nominal \\
\hline $\begin{array}{l}\text { Operasi Perusahaan } \\
\text { (X1) }\end{array}$ & $\begin{array}{l}1=\text { Memiliki anak perusahaan } \\
0=\text { Tidak memiliki anak perusahaan }\end{array}$ & \\
\hline Ukuran KAP (X2) & $\begin{array}{l}\text { Variabel dummy, } \\
1=\text { KAP Big } 4 \\
0=\text { KAP non Big } 4\end{array}$ & Nominal \\
\hline Audit Tenure (X3) & $\begin{array}{l}\text { Menghitung jumlah tahun perikatan di mana KAP yang sama } \\
\text { melakukan perikatan audit terhadap auditee, tahun pertama } \\
\text { perikatan dimulai dengan angka } 1 \text { dan ditambah dengan satu } \\
\text { untuk tahun-tahun berikutnya. }\end{array}$ & Nominal \\
\hline
\end{tabular}

Uji Kualitas Data dalam penelitian ini dilakukan dengan menggunakan uji asumsi klasik yang terdiri dari Uji Normalitas, Uji Mulitikolinearitas, Uji Autokorelasi dan Uji Heterokedastisitas. Metode analisis data dalam penelitian ini adalah analisis statistik deskriptif, statistik Deskriptif adalah statsitik yang digunakan untuk menganalisis data dengan cara mendeskripsikan atau menggambarkan data yang telah terkumpul sebagaimana adanya tanpa bermaksud membuat kesimpulan yang berlaku umum atau generalisasi (Sugiyono, 2012, 147). Dalam statistik deskriptif penelitian ini, data diolah dan disajikan berdasarkan periode dan karakteristik data, juga dengan membuat tabel distribusi kategori untuk audit delay dengan menggunakan deskripsi dengan angka di mana dalam penelitian ini menggunakan range antara angka minimal hingga angka maksimal.

Teknik penumpulan data dalam penelitian ini adalah teknik teknik dokumentasi yaitu: kajian pustaka, yaitu dengan mencari literatur yang berhubungan dengan penelitian ini, baik dari buku, jurnal, skripsi, thesis, dan pengumpulan data melalui media internet, yaitu dengan cara mengunduh laporan keuangan tahunan perusahaan yang telah diaudit melalui website Bursa Efek Indonesia (www.idx.co.id) untuk memperoleh data dan informasi yang dibutuhkan dalam penelitian ini. Model dan teknik analisa data penelitian menggunakan pendekatan regresi linear berganda dalam penelitian ini dapat dirumuskan sebagai berikut : 


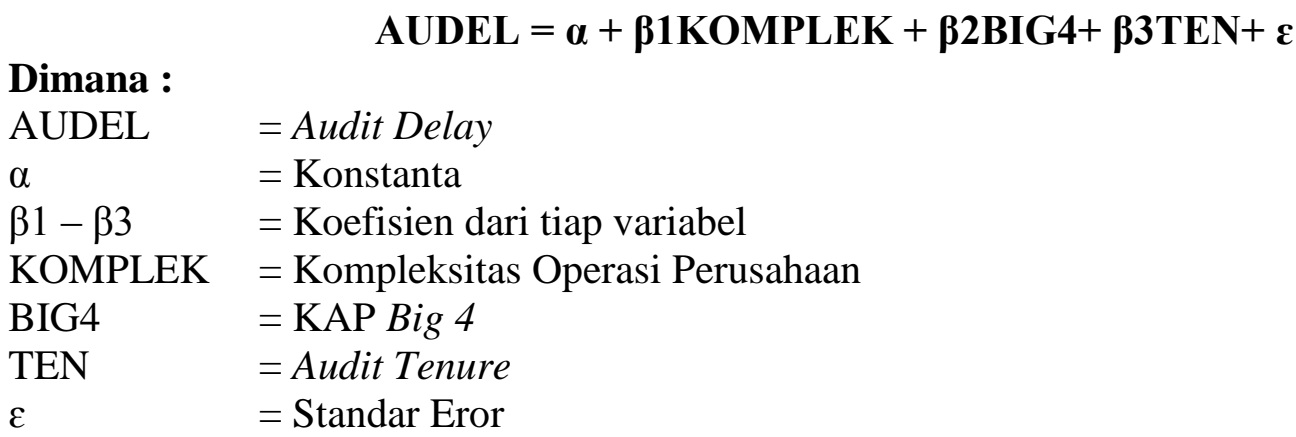

Arti koefisien $\beta$ adalah jika nilai $\beta$ positif (+), hal tersebut menunjukkan hubungan yang searah antara variabel independen dengan variabel dependen. Dengan kata lain peningkatan atau penurunan besarnya variabel independen akan diikuti oleh peningkatan atau penurunan besarnya variabel dependen. Sedangkan jika $\beta$ negatif (-), menunjukkan hubungan yang berlawanan antara variabel independen dengan variabel dependen.

\section{ISI}

\section{PENGUMPULAN DATA}

Populasi dalam penelitian ini adalah seluruh perusahaan manufaktur yang terdaftar di Bursa Efek Indonesia sebanyak 143 perusahaan yang terdaftar selama periode 2011-2015. Metode penentuan sampel yang dilakukan adalah metode puposive sampling yakni sampel berdasarkan kriteria-kriteria yang telah ditentukan. Berikut ini tabel 2 yang menggambarkan seleksi sampel penelitian.

Dari 143 perusahaan manufaktur yang terdaftar di BEI dari tahun 20112015 yang terpilih sesuai kriteria yang ada hanya terdapat 95 perusahaan yang sesuai dengan kriteria diatas, dan akan digunakan sebagai sampel penelitian dan jumlah tahun penelitian sebanyak 5 (lima) periode pengamatan sebanyak 475 pengamatan.

Tabel 2. Seleksi Sampel Penelitian

\begin{tabular}{lr}
\hline Keterangan & Jumlah \\
\hline Populasi & 143 \\
Perusahaan yang tidak masuk kriteria-kriteria sampel penelitian : & 2 \\
Perusahaan manufaktur yang mengalami delisting dan relisting selama periode 2011-2015 & 5 \\
Baru melakukan IPO (Initial Public Offering) selama periode 2011-2015 & 2 \\
Perusahaan mengalami pindah sektor selama periode 2011-2015 & 18 \\
Perusahaan yang tidak melampirkan laporan auditor independen di dalam laporan & \\
keuangan tahunan pada periode 2011-2015 dan tidak memiliki tahun buku yang berakhir & 21 \\
pada tanggal 31 Desember & 48 \\
Perusahaan menggunakan mata uang US Dollar dalam laporan keuangannya. & 95 \\
Jumlah perusahaan yang tidak termasuk sampel & 5 \\
Jumlah perusahaan yang memenuhi kriteria sampel & 475 \\
Tahun pengamatan (Tahun) & \\
\hline Jumlah unit analisis &
\end{tabular}




\section{ANALISIS DATA STATISTIK DESKRIPTIF}

Keabsahan suatu hasil penelitian sangat ditentukan oleh metode analisis data yang digunakan dalam suatu penelitian guna memperoleh hasil yang menggambarkan keadaan yang sesungguhnya. Metode analisis data pada penelitian ini adalah sebagai berikut. Statistik Deskriptif adalah statistik yang digunakan untuk menganalisis data dengan cara mendeskripsikan atau menggambarkan data yang telah terkumpul sebagaimana adanya tanpa bermaksud membuat kesimpulan yang berlaku umum atau generalisasi (Sugiyono, 2012, 147).

Berdasarkan tabel 3, statistik deskriptif di atas menunjukkan bahwa variabel audit delay memiliki nilai terendah (minimum) adalah sebesar 33, menandakan terdapat perusahaan yang hanya membutuhkan waktu 33 hari untuk menyampaikan laporan keuangan tahunan yang telah diaudit kepada OJK terhitung dari tanggal tutup buku laporan keuangan. Variabel independen kompleksitas operasi perusahaan dibedakan menjadi 2 kategori yaitu perusahaan yang memiliki anak perusahaan dengan nilai 1 dan tidak memiliki anak perusahaan dengan nilai 0 . Hasil analisis deskriptif diperoleh nilai rata-rata sebesar 0,6968 dan standar deviasi sebesar 0,46011. Berikut adalah statistik deskriptif kompleksitas operasi perusahaan (Tabel 4).

Variabel ukuran KAP dibedakan menjadi 2 kategori yaitu perusahaan yang menggunakan jasa KAP Big 4 dengan nilai 1 dan yang menggunakan jasa KAP Non Big 4 dengan nilai 0 . Hasil analisis deskriptif diperoleh nilai rata-rata sebesar 0,4358 dan standar deviasi sebesar 0,49638. Berikut adalah statistik deskriptif ukuran KAP (Tabel 5).

Tabel 3. Statistik deskriptif

\begin{tabular}{lrrrrr}
\hline & N & Minimum & Maximum & \multicolumn{1}{c}{ Mean } & \multicolumn{1}{c}{ Std Deviation } \\
\hline KOMPLEK & 475 &, 00 & 1,00 &, 6968 &, 46011 \\
BIG4 & 475 &, 00 & 1,00 &, 4358 &, 49638 \\
TEN & 475 & 1,00 & 5,00 & 2,6400 & 1,38058 \\
AUDEL & 475 & 33,00 & 271,00 & 80,6821 & 24,48383 \\
\hline
\end{tabular}

Sumber : Data yang diolah, 2017

Tabel 4. Statistik Deskriptif Kompleksitas Operasi Perusahaan

\begin{tabular}{ccc}
\hline Keterangan & Jumlah & Persentase \\
\hline Memiliki anak perusahaan & 331 & $69,7 \%$ \\
Tidak memiliki anak perusahaan & 144 & $30,3 \%$ \\
\hline Total & 475 & $100 \%$ \\
\hline
\end{tabular}

Sumber : Data yang diolah, 2017 
Tabel 5. Statistik Deskriptif Ukuran KAP

\begin{tabular}{lccc}
\hline & Keterangan & Jumlah & Persentase \\
\hline Big 4 & & 207 & $43,6 \%$ \\
Non Big 4 & & 268 & $56,4 \%$ \\
\hline \multicolumn{2}{r}{ Total } & 475 & $100 \%$ \\
\hline \multicolumn{2}{c}{ Sumber : Data yang diolah 2017} & &
\end{tabular}

Sumber : Data yang diolah, 2017

Nilai audit tenure terendah (minimum) adalah 1 dan yang terbesar (maximum) adalah 5 yaitu untuk jumlah tahun perikatan KAP yang sama dengan perusahaan manufaktur selama 5 tahun berturut-turut. Hasil analisis deskriptif diperoleh nilai rata-rata sebesar 2,6400 dan standar deviasi sebesar 1,38058.

\section{PENGUJIAN HIPOTESIS}

Berdasarkan tabel 6 di atas, variabel kompleksitas operasi perusahaan menunjukkan koefisien regresi sebesar 0,001. Nilai $\mathrm{t}$ hitung sebesar $-0,079$. Sementara $t$ tabel yang diperoleh dengan melihat derajat kebebasan (df) n-k-1 dengan jumlah sampel sebanyak 271, variabel bebas $(\mathrm{k})$ sebanyak 3 atau (df) 271-3-1 = 267 maka diperoleh $\mathrm{t}$ tabel sebesar 1,969, variabel kompleksitas operasi perusahaan menunjukkan nilai -
$0,079<1,969$ dengan tingkat signifikansi sebesar 0,937 >0,05. Maka hipotesis 1 dapat disimpulkan bahwa $\mathrm{H}_{01}$ diterima dan $\mathrm{H}_{\mathrm{a} 1}$ ditolak. Sehingga kompleksitas operasi perusahaan tidak memiliki pengaruh terhadap audit delay. Variabel ukuran KAP menunjukkan koefisien regresi sebesar 0,032 . Nilai $\mathrm{t}$ hitung $<\mathrm{t}$ tabel sebesar $2,923<1,969$ dengan tingkat signifikansi sebesar $0,004<0,05$, maka hipotesis kedua berhasil didukung. Maka hipotesis 2 dapat disimpulkan bahwa $\mathrm{H}_{02}$ ditolak dan $\mathrm{H}_{\mathrm{a} 2}$ diterima. Sehingga ukuran KAP berpengaruh negatif terhadap audit delay. Variabel audit tenure menunjukkan koefisien regresi sebesar 0,004. Nilai $\mathrm{t}$ hitung $<\mathrm{t}$ tabel sebesar $1,116<1,969$ dengan tingkat signifikansi sebesar 0,265 $>$ 0,05. Maka hipotesis 3 dapat disimpulkan $\mathrm{H}_{03}$ diterima dan $\mathrm{H}_{\mathrm{a} 3}$ ditolak. Sehingga audit tenure tidak berpengaruh terhadap audit delay.

Tabel 6. Uji Signifikansi Parameter Individual (Uji t) Manufaktur Coefficents $^{\mathrm{a}}$

\begin{tabular}{lrrrrr}
\hline \multirow{1}{*}{ Model } & \multicolumn{2}{c}{$\begin{array}{l}\text { Unstandardized } \\
\text { Coefficients }\end{array}$} & $\begin{array}{l}\text { Standardized } \\
\text { Coefficients }\end{array}$ & T & \multirow{2}{*}{ Sig. } \\
\cline { 2 - 4 } & \multicolumn{1}{c}{ B } & \multicolumn{1}{c}{ Std. Eror } & \multicolumn{1}{c}{ Beta } & & \\
\hline 1 (Constant) & 4,396 &, 013 & & 339,505 & 0,000 \\
KOMPLEK &,- 001 &, 011 &,- 005 &,- 079 &, 937 \\
BIG4 &,- 032 &, 011 &,- 180 & $-2,923$ &, 004 \\
TEN &, 004 &, 004 &, 068 & 1,116 &, 265 \\
\hline
\end{tabular}

a. Dependent Variable: LNAUDEL Sumber : Output SPSS, 2017 
Hasil uji signifikan parameter individual (Uji t) dapat dilihat pada (Tabel 6). Bedasarkan nilai hasil uji statistik $\mathrm{t}$ maka diperoleh persamaan regresi berganda sebagai berikut :

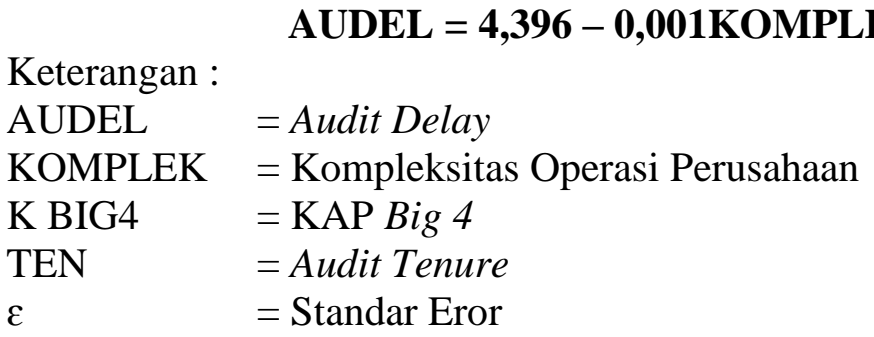

Tabel 7. Uji Simultan (Uji F) Manufaktur)

\begin{tabular}{lrrrrr}
\hline \multicolumn{1}{c}{ Model } & $\begin{array}{l}\text { Sum Of } \\
\text { Squares }\end{array}$ & df & \multicolumn{1}{c}{$\begin{array}{c}\text { Mean } \\
\text { Square }\end{array}$} & F & Sig. \\
\hline Regression &, 065 & 3 &, 022 & 3,013 &, $013^{\text {b }}$ \\
Residual & 1,909 & 267 &, 007 & & \\
Total & 1,974 & 270 & & & \\
\hline
\end{tabular}

a. Dependent Variable: LNAUDEL

b. Predictors: (Constant), TEN, KOMPLEK, BIG4

Sumber: Output SPSS, 2017.

Berdasarkan hasil uji simultan (Uji F) diperoleh nilai F sebesar 3,013 dengan nilai Sig 0,031. Nilai sig ini lebih kecil dari tingkat signifikansi 5\% yang ditetapkan dalam penelitian sehingga dapat disimpulkan bahwa variabelvariabel independen yaitu kompleksitas operasi perusahaan, ukuran KAP, dan audit tenure secara simultan berpengaruh signifikan terhadap lamanya audit delay pada periode tahun 2011-2015, seperti dijelaskan didalam Tabel 7.

Hasil penelitian menunjukkan kompleksitas operasi perusahaan tidak berpengaruh terhadap audit delay. Hasil penelitian ini mendukung penelitian Mustafa (2011) yang menemukan bahwa kompleksitas operasi perusahaan tidak berpengaruh terhadap audit delay. Hal ini disebabkan meskipun perusahaan tersebut mempunyai jaringan koordinasi dan operasional yang lebih rumit akibat adanya anak perusahaan namun dengan sistem informasi akuntansi yang baik dan sistem pengendalian internal yang memadai maka proses pembuatan dan penyampaian laporan keuangan perusahaan akan tepat pada waktunya.

Ukuran KAP berpengaruh negatif terhadap audit delay. Hasil penelitian ini mendukung penelitian Prasongkoputra (2013) dan Puspitasari \& Latrini (2014), yang menunjukkan bahwa ukuran KAP berpengaruh secara signifikan terhadap audit delay. Hal ini menunjukkan bahwa kantor KAP Big 4 membutuhkan waktu yang lebih singkat dalam menyelesaikan audit secara efisien dan memiliki fleksibilitas jadwal waktu yang lebih tinggi untuk menyelesaikan audit tepat pada waktunya disamping mereka memiliki sumber daya manusia yang lebih banyak serta memiliki pengalaman yang lebih banyak dari KAP lainnya. 
Disamping itu, KAP besar memperoleh insentif yang lebih tinggi untuk menyelesaikan pekerjaan auditnya dibandingkan KAP kecil. Waktu audit yang lebih cepat merupakan cara KAP besar untuk mempertahankan reputasi mereka

Audit tenure tidak berpengaruh terhadap audit delay. Hasil penelitian ini sejalan dengan penelitian yang dilakukan Praptika \& Rasmini (2016) dan Rustiarini \& Sugiarti (2013) yang menyatakan bahwa audit tenure tidak berpengaruh terhadap audit delay. Hal ini disebabkan karena walaupun perusahaan menggunakan jasa KAP yang sama selama 6 tahun berturut-turut sesuai dengan Peraturan Menteri Keuangan No. 17/PMK.01/2008 tentang pembatasan lamanya masa penugasan auditor dengan perusahaan klien, namun banyak terjadinya pergantian auditor selama masa penugasan yang kurang dari 3 tahun buku berturut-turut. Sehingga terjadi kegagalan audit yang mengakibatkan durasi audit delay yang lebih panjang karena auditor dengan tenure yang lebih pendek belum memiliki pemahaman yang mendalam dan memadai tentang perusahaan.

\section{PENUTUP}

Berdasarkan hasil penelitian yang telah dilakukan dapat disimpulkan bahwa variabel kompleksitas operasi perusahaan tidak berpengaruh terhadap audit delay pada perusahaan manufaktur yang terdaftar di Bursa Efek Indonesia. Variabel ukuran KAP berpengaruh negatif terhadap audit delay pada perusahaan manufaktur yang terdaftar di Bursa Efek Indonesia. Audit tenure tidak berpengaruh terhadap audit delay pada perusahaan manufaktur yang terdaftar di Bursa Efek Indonesia.

Untuk kesempurnaan penelitian selanjutnya, sebaiknya menambahkan jumlah data dan lingkup penelitian. Serta menambahkan variabel independen seperti profitabilitas, likuiditas, solvabilitas, leverage, laba perusahaan, ROE, umur perusahaan, opini audit, deb proportion, auditor change, dan lain-lain. Dan bagi regulator dapat memberikan kontribusi dalam merumuskan kebijakan, peraturan, dan standar dalam upaya untuk menyempurnakan aturan-aturan bagi Kantor Akuntan Publik. Serta bagi perusahaan diusahakan menggunakan hartanya untuk mendekatkan diri kepada Allah SWT. diharapkan dapat membantu manajemen perusahaan dalam mengidentifikasi faktor-faktor yang mempengaruhi audit delay sehingga dapat mempersingkat waktu penyampaian laporan sesuai dengan aturan waktu yang telah ditentukan oleh OJK.

\section{DAFTAR PUSTAKA}

Ardianti, Fanie. 2013. “Analisis FaktorFaktor Yang Berpengaruh Terhadap Audit Delay (Studi Pada Perusahaan Manufaktur Yang Terdaftar Di Bursa Efek Indonesia Tahun 2009-2012)". Skripsi, Fakultas Ekonomika Dan Bisnis Universitas Diponegoro Semarang.

Fitriyani, Chintya Ayu, Pupung Purnamasari, Mey Maemunah. 2015. "Pengaruh Tenure Audit, Ukuran KAP, dan Kompleksitas Operasi Perusahaan Terhadap Audit Report Lag ( Studi Kasus Pada Perusahaan Consumer Goods Yang Terdaftar Di BEI Periode 2010-2014)”. Prosiding Akuntansi, 
Fakultas Ekonomi Dan Bisnis Universitas Islam Bandung. ISSN: 2460-6561.

Ghozali, Imam. 2011. “Aplikasi Analisis Multivariate Dengan Program SPSS'.Semarang: BP Universitas Diponegoro.

Ilhami, Maulana Fiqi. 2015. "Audit Report Lag, "Penyakit" Tahunan Perusahaan". http://www.kompasiana.com/maula nafiqi/audit-report-lag-penyakittahunanperusahaan_557007cc307a61a346b bf125. 17 Juni 2015.

Kholishah, Siti Aliyah Nur. 2013. "Pengaruh Penerapan Ifrs, Ukuran Perusahaan, Profitabilitas, Dan Kompleksitas Terhadap Audit Delay (Studi Empiris Pada Perusahaan Manufaktur Yang Terdaftar Di Bursa Efek Indonesia Pada Tahun 2008-2011)”. Skripsi, Jurusan Akuntansi Fakultas Ekonomi Dan Bisnis Universitas Islam Negeri Syarif Hidayatullah Jakarta.

MarhaYaacob, Najihah dan Ayoib CheAhmad. 2012. "Adoption FRS 138 and Audit Delay in Malaysia". International Journal of Economics and Finance, Vol. 4 No. 1.

Melani, Agustina. 2016. "Telat Sampaikan Laporan Keuangan, BEI Suspensi Saham 14 Emiten". http://bisnis.liputan6.com/read/264 0421/telat-sampaikan-laporankeuangan-bei-suspensi- saham-14 emiten? source $=$ search. November 2016.

Mustafa, Fery Listyanto. 2011. "Pengaruh Karakteristik Perusahaan, Kompleksitas Operasi Peruahaan, Dan Reputasi Kantor Akuntan Publik (KAP) Terhadap Ketepatan Waktu Penyampaian
Laporan Keuangan (Studi Empiris pada Perusahaan Manufaktur yang Terdaftar di Bursa Efek Indonesia Periode 2007-2009)". Skripsi. Fakultas Ekonomi Universitas Sebelas Maret Surakarta

Otoritas Jasa Keuangan. 2016. "Peraturan Otoritas Jasa Keuangan Nomor 42 /Pojk.04/2016 Tentang Laporan Bursa Efek". Jakarta: Dewan Komisioner Otoritas Jasa Keuangan.

Praptika, Putu Yulia Hartanti dan Ni Ketut Rasmini. 2016. "Pengaruh Audit Tenure, Pergantian Auditor Dan Financial Distress Pada Audit Delay Pada Perusahaan Consumer Goods". E-Jurnal Akuntansi Universitas Udayana Bali, Vol.15.3. Juni (2016): 2052-2081. ISSN: 2302-8556.

Prasongkoputra, Adinugraha. 2013. "Faktor-Faktor Yang Mempengaruhi Audit Delay". Skripsi, Fakultas Ekonomi Dan Bisnis Uin Syarif Hidayatullah Jakarta.

Ratnaningsih, Ni Made Dwita dan A.A.N.B.Dwirandra. 2016. "Spesialisasi Auditor Sebagai Variabel Pemoderasi Pengaruh Audit Tenure Dan Pergantian Auditor Pada Audit Delay". EJurnal Akuntansi Universitas Udayana Bali, Vol.16.1. Juli(2016): 18-44. ISSN: 2302-8556.

Rustiarini, Ni Wayan dan Ni Wayan Mita Sugiarti. 2013. "Pengaruh Karakteristik Auditor, Opini Audit, Audit tenure, Pergantian Auditor Pada Audit Delay". Jurnal Ilmiah Akuntansi dan Humanika JINAH Singaraja, Vol 2, No 2. Juni 2013. ISSN 2089-3310.

Setyaningrum, Indah. 2015. "FaktorFaktor Yang Mempengaruhi Audit 
Report Lag Pada Perushaan Consumer Goods Industry Dan Multifinance Yang Terdaftar Di Bursa Efek Indonesia (Studi Empiris Di Bursa Efek Indonesia Tahun 2009 Sampai 2013)”. Naskah Publikasi, Program Studi Akuntansi Fakultas Ekonomi Dan Bisnis Universitas Muhammadiyah Surakarta.
Sugiyono. 2012. "Metode Penelitian Kuantitatif Kualitatif dan $R \& B$ ". Bandung: Alfabeta.

Suryanto. 2012. "Terlambat serahkan Laporan Keuangan preseden buruk".

http://www.antaranews.com/berita/ 320172/terlambat-serahkanlaporan-keuangan-preseden-buruk. 6 Juli 2012.

www.idx.co.id 